\title{
COVID-19 Compared to Other Pandemic Diseases
}

\author{
Silvio Daniel Pitlik, M.D.** \\ Infectious Diseases, Mayanei Hayeshua Medical Center, Bnei Brak, Israel
}

\begin{abstract}
In December 2019, the first cases of a new contagious disease were diagnosed in the city of Wuhan, the capital of Hubei province in China. Within a short period of time the outbreak developed exponentially into a pandemic that infected millions of people, with a global death toll of more than 500,000 during its first 6 months. Eventually, the novel disease was named coronavirus disease 2019 (COVID-19), and the new virus was identified as severe acute respiratory syndrome coronavirus 2 (SARS-CoV-2). Similar to all known pandemics throughout history, COVID-19 has been accompanied by a large degree of fear, anxiety, uncertainty, and economic disaster worldwide. Despite multiple publications and increasing knowledge regarding the biological secrets of SARS-CoV-2, as of the writing of this paper, there is neither an approved vaccine nor medication to prevent infection or cure for this highly infectious disease. Past pandemics were caused by a wide range of microbes, primarily viruses, but also bacteria. Characteristically, a significant proportion of them originated in different animal species (zoonoses). Since an understanding of the microbial cause of these diseases was unveiled relatively late in human history, past pandemics were often attributed to strange causes including punishment from God, demonic activity, or volatile unspecified substances.
\end{abstract}

\begin{abstract}
Abbreviations: AIDS, acquired immune deficiency syndrome; COVID-19, coronavirus disease 2019; DNA, deoxyribonucleic acid; Flu, influenza; gRNA, guide ribonucleic acid; H1N1, hemagglutinin-1 neuraminidase-1; H2N2, hemagglutinin-2 neuraminidase-2; $\mathrm{H}_{3} \mathrm{~N} 2$, hemagglutinin-3 neuraminidase-2; MERS, Middle East respiratory syndrome; MERS-CoV, Middle East respiratory syndrome coronavirus; RNA, ribonucleic acid; SARS, severe acute respiratory syndrome; SARS-CoV-2, severe acute respiratory syndrome coronavirus-2; spp, species; US, United States; WHO, World Health Organization.
\end{abstract}

Citation: Pitlik SD. COVID-19 Compared to Other Pandemic Diseases. Rambam Maimonides Med J 2020;11 (3):eoo27. Review. doi:10.5041/RMMJ.10418

Copyright: (C) 2020 Silvio D. Pitlik. This is an open-access article. All its content, except where otherwise noted, is distributed under the terms of the Creative Commons Attribution License (http://creativecommons.org/licenses/by/3.o), which permits unrestricted use, distribution, and reproduction in any medium, provided the original work is properly cited.

Acknowledgement: To my daughter Karin Pitlik (Illustration LinkedIn-Karin Pitlik) who drew the figures and to my wife Nina Pitlik who helped me with gathering the references and typing the manuscript.

Conflict of interest: No potential conflict of interest relevant to this article was reported.

* E-mail: silviopitlik@gmail.com 
Although a high case fatality ratio was common to all pandemic diseases, some striking clinical characteristics of each disease allowed contemporaneous people to clinically diagnose the infection despite null microbiological information. In comparison to past pandemics, SARS-CoV-2 has tricky and complex mechanisms that have facilitated its rapid and catastrophic spread worldwide.

KEY WORDS: COVID-19, comparison, history, pandemics, SARS-CoV-2

\section{INTRODUCTON}

On January 10, 2020, the genome of a new coronavirus, now known as severe acute respiratory syndrome coronavirus 2 (SARS-CoV-2), was posted on the internet. ${ }^{1}$ It had been isolated days before from patients developing varying degrees of pneumonia in Wuhan, the capital of Hubei province in China. ${ }^{2}$ Immediately thereafter, a growing number of scientists worldwide became deeply involved in analyzing its molecular details. ${ }^{3}$ One of the major tasks that they focused on was synthetizing the proteins encoded by the viral RNA and deciphering their structure and function. Acutely aware of the pandemic potential of SARS-CoV-2, some of these scientists immediately alerted selected vaccine producers, with the hope of triggering a swift process for vaccine design and development.4,5 Once the protein amino acid composition and the post folding structure of close to 30 proteins in SARS-CoV-2 were defined, multiple computational searches were launched by a number of institutions, looking to repurpose extant drugs aimed against the newly discovered molecular targets. ${ }^{6}$ In parallel to this accelerated research, there was a marked and frightening spread of this new coronavirus throughout Wuhan to a widening area in China, and it was subsequently exported to a rapidly growing list of countries worldwide. ${ }^{7,8}$

This paper reviews the microbiological, clinical, and epidemiological characteristics of the coronavirus disease 2019 (COVID-19) pandemic, as well as its socio-economic impact. In addition, COVID-19 is compared to previous pandemics in human history.

\section{UNDERSTANDING SARS-COV-2}

In the early days of the pandemic great effort was invested into understanding the life cycle of SARS$\mathrm{CoV}-2,{ }^{9}$ so as to provide a basis for discovery of an effective vaccine to prevent COVID-19 and/or a safe and efficacious drug to cure it, or at the least, to ameliorate its symptoms, shorten its duration, and/ or block its mechanism of transmission. Being a virus, SARS-CoV-2 must invade host cells, hijack the cell's biologic machinery for reproduction, and, finally, release multiple daughter virions. Research uncovered six steps in the life cycle of SARS-CoV-2: (1) attachment and entry; (2) uncoating; (3) guide ribonucleic acid (gRNA) replication; (4) translation in the endoplasmic reticulum and Golgi apparatus; (5) assembly; and (6) virion release..$^{10,11}$

The external surface of SARS-CoV-2 has multiple protruding elements called spike proteins which, after manipulation by host cell enzymes (furin and TMPRSS2), function as anchors for attachment to the host cells. ${ }^{12,13}$ The cell surfaces of the upper and lower respiratory tract are covered with angiotensinconverting enzyme-2 (ACE2) receptors, which are physiologically involved in blood pressure regulation. ${ }^{13}$ However, these receptors are also present in many other organs and tissues, helping to explain some of the extra-respiratory manifestations of COVID-19.14 Once attached to the external membrane, SARS-CoV-2 covers itself with a portion of the host cell membrane and becomes an intracellular endosome. This structure undergoes partial uncoating allowing the release of gRNA into the cytoplasm of the host cell. The released strands of gRNA attach to host ribosomes, RNA-dependent RNA polymerase (RdRp), and together activate the gRNA replication mechanism. Other released strands of gRNA undergo translation into structural, nonstructural, and coat proteins. ${ }^{9}$ The different basic blocks of the reproduced virus are finally assembled into multiple virions that are expelled to the extracellular space of the host. 9 These released daughter virions are now ready to infect other cells or, even worse, other hosts.

Once these mechanisms had been clarified, multiple hypotheses relating to specific actions of different drugs were proposed. For example, chloroquine, hydroxychloroquine, and azithromycin all inhibit the uncoating of the invading endosomes. On the other hand, the antivirals remdesivir and favipiravir inhibit gRNA replication by RdRp. Additional drugs, not only antivirals, have also been identified to tar- 
get the complex mechanisms of the intracellular viral cycle. ${ }^{15}$

\section{ANIMAL AND HUMAN CORONAVIRUS}

The first human coronavirus was described by June Dalziel Almeida in 1966. She had observed a viral structure seen under electron microscopy while being involved in a study investigating causes of the common cold. A paper submitted by Almeida and her team described a crown-shaped structure supposed to be a new type of virus causing common colds. This paper was rejected as the editors claimed that "these microscopic observations resulted from distorted influenza viruses." 16,17 Since this pioneering observation, around 100 species of viruses in the subfamily Coronaviridae have been described, the majority of which were found in animals, primarily though not only in bats. ${ }^{18}$ Only some of the animal coronaviruses had been associated with a specific animal disease such as a severe type of bronchitis in poultry. ${ }^{17}$ On the other hand, many of these coronaviruses were isolated from healthy animals, again predominantly bats.

Based on current knowledge, there are seven species of human coronaviruses. ${ }^{19}$ Four of them (Figure 1 , Table 1 ) cause a mild upper respiratory tract infection manifested as a runny nose. Occasionally, they involve the lower respiratory tract. The remaining three human coronaviruses are associated with a wider spectrum of disease severity. Relatively frequently they cause severe pneumonia and other serious complications (Figure 1, Table 1). As indicated in Figure 1, five of the seven human coronaviruses have well established intermediate hosts, based on both epidemiologic and genomic data. In the case of COVID-19, preliminary data suggest that several species of pangolins are the suspected intermediate host. Pangolins are mammals covered by keratin scales. In China the pangolin is seen as an edible animal mainly, but traditional medicine in this country

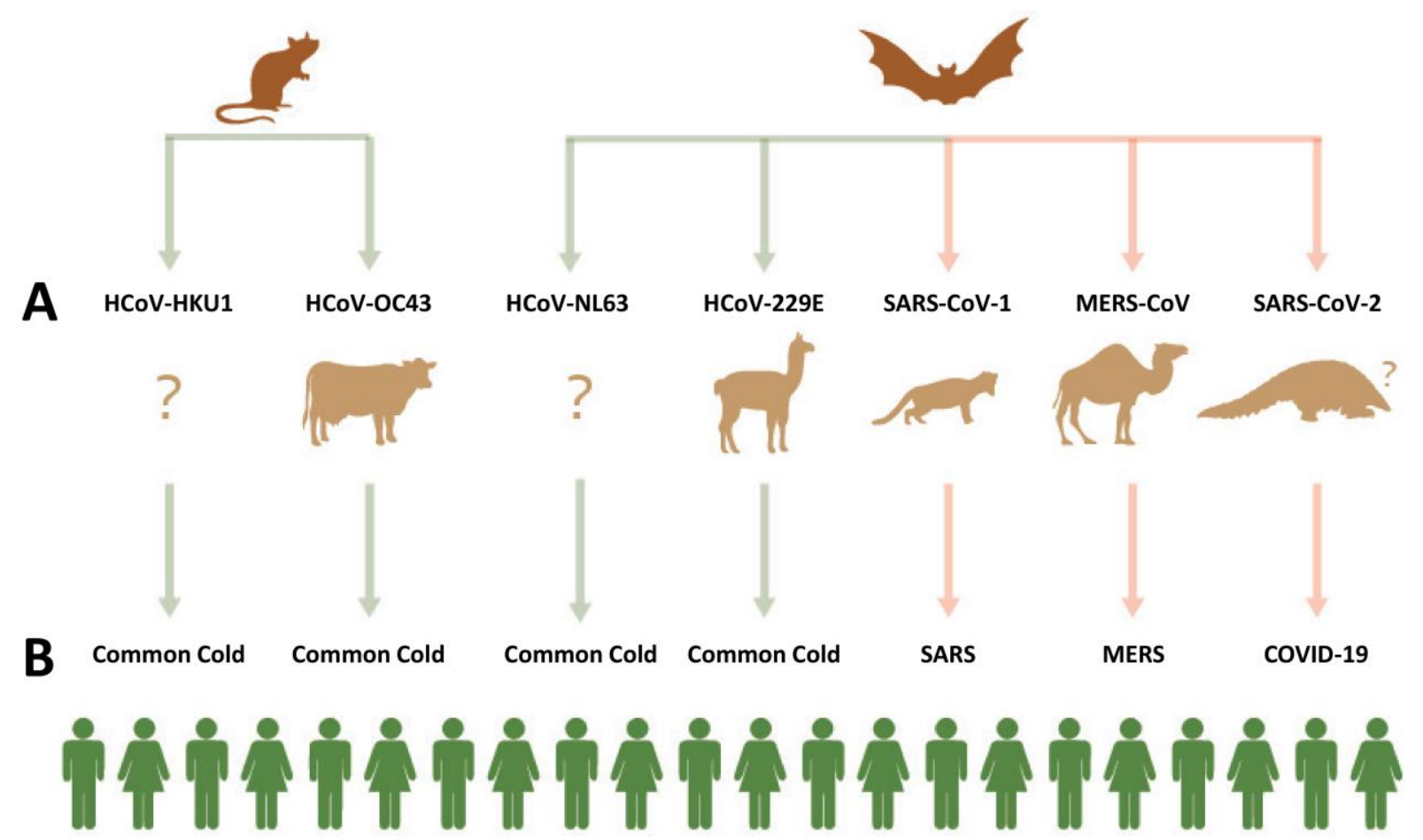

Figure 1. Zoonotic Origin of Human Coronaviruses (A) and the Resulting Diseases (B). Upper line, reservoir hosts; middle line, intermediate hosts; bottom line, infected human hosts.

COVID-19, coronavirus disease 2019; HCoV-229E, human coronavirus 229E; HCoV-NL63, human coronavirus Netherlands 63; HCoV-OC43, human coronavirus OC43; HCoV-HKU1, human coronavirus Hong Kong U1; MERS, Middle East respiratory syndrome; MERS-CoV, Middle East respiratory syndrome coronavirus; SARS, severe acute respiratory syndrome; SARS-CoV-1, severe acute respiratory syndrome coronavirus-1; SARS-CoV-2, severe acute respiratory syndrome coronavirus-2. 
Table 1. Known Human Diseases Caused by a Coronavirus (see also Figure 1).

\begin{tabular}{|c|c|c|c|c|c|c|}
\hline Disease & Virus & $\begin{array}{c}\text { Main } \\
\text { Manifestation(s) }\end{array}$ & Hospitalization & $\begin{array}{l}\text { Antiviral } \\
\text { Therapy }\end{array}$ & Vaccine & $\begin{array}{c}\text { Case } \\
\text { Fatality (\%) }\end{array}$ \\
\hline Common cold & HCoV-HKU1 & Runny nose* & Very rare & None & None & 0 \\
\hline Common cold & HCoV-OC43 & Runny nose* & Very rare & None & None & 0 \\
\hline Common cold & HCoV-NL63 & Runny nose* & Very rare & None & None & 0 \\
\hline Common cold & HCoV-229E & Runny nose* & Very rare & None & None & 0 \\
\hline SARS & SARS-CoV-1 & Pneumonia & Very frequent & None & None & 9.5 \\
\hline MERS & MERS-CoV & Pneumonia & Very frequent & None & None & 34.4 \\
\hline COVID-19 & SARS-CoV-2 & $\begin{array}{c}\text { Respiratory } \\
\text { tract infection }\end{array}$ & Frequent & Remdesivir & None ${ }^{\ddagger}$ & $>1.6^{\mathrm{s}}$ \\
\hline
\end{tabular}

* Rare: lower respiratory tract infection (bronchitis or pneumonia).

† Upper respiratory tract infection frequent, pneumonia in a minority of patients.

$\ddagger 125$ different vaccines in various phases of development, none yet approved.

${ }^{\S}$ Case fatality value varies with population characteristics, age distribution, quality of healthcare services, medical equipment, etc.

COVID-19, coronavirus disease 2019; HCoV-229E, human coronavirus 229E; HCoV-HKU1, human coronavirus Hong Kong U1; HCoV-NL63, human coronavirus Netherlands 63; HCoV-OC43, human coronavirus OC43; MERS-CoV, Middle East respiratory syndrome coronavirus; SARS-CoV-1, severe acute respiratory syndrome-coronavirus-1; SARS-CoV-2, severe acute respiratory syndrome coronavirus- 2 .

also attributes multiple curative properties to a powder obtained by mashing their scales. ${ }^{20,21}$

Although the transmissibility of both severe acute respiratory syndrome (SARS) and Middle East respiratory syndrome (MERS) is lower than that of COVID-19, the case fatality ratio is many times higher for MERS and SARS than for COVID-19 (Table 1). ${ }^{22}$ However, the number of COVID-19 cases have markedly outnumbered the number of cases in both SARS and MERS. While clinical manifestations for the two last-mentioned infections were generally limited to the respiratory tract, although with higher degrees of disease severity, it is remarkable that there has been a wide spectrum of heterogeneous clinical manifestations in COVID-19 cases. From a pathophysiological perspective, this phenomenon is explained by the ubiquitous presence of ACE2 receptors throughout multiple organs and blood vessels. At a clinical level, some typical COVID-19 manifestations described during the pandemic include "silent anoxia," 23 a discrepancy between an extremely low oxygen level as measured by pulse oximeter and the simultaneous lack of dyspnea; signs of cardiac involvement including myocarditis, myocardial ischemia, and myocardial infarction ${ }^{24}$; hepatitis ${ }^{25}$; reddish discoloration of the toes mimicking frostbite or chilblains ${ }^{26}$; intravascular coagulation including pulmonary embolism ${ }^{27}$; encephalitis ${ }^{28}$; and acute renal failure (see also Table 2). ${ }^{29}$ Recently a condition similar to Kawasaki syndrome was described in a growing number of teenagers (as opposed to toddlers with classical Kawasaki syndrome); it has been proposed to name the syndrome "pediatric multisystem inflammatory syndrome." 30 The mechanism of this complication is an overreaction of the immune system. A comparison of the leading clinical identifiers of recognized pandemic diseases is provided in Table 2.

\section{DEFINITION OF PANDEMICS}

The simplest definition of a pandemic is a contagious infectious disease that has spread to multiple geographic areas or continents. The term "contagious" implies that the infection can be transmitted person-to-person, either directly or indirectly. Various degrees of controversy emerge between members of the medical and scientific communities when defining a new disease as pandemic. According to the World Health Organization (WHO), "a pandemic is the worldwide spread of a new disease." ${ }^{1}$ However, even this condensed and crisp definition, not infrequently, leaves room for discussion. A 2009 convention, held at the beginning of the $\mathrm{H} 1 \mathrm{~N} 1$ pandemic under the umbrella of the National Institutes 
Table 2. Leading Clinical Identifiers of Recognized Pandemic Diseases.

\begin{tabular}{ll}
\hline Disease & \multicolumn{1}{c|}{ Salient Clinical Features } \\
\hline Smallpox & Typical widespread vesiculo-pustular rash, occasionally corneal opacification \\
Measles & Morbilliform rash, Koplik's spots, conjunctivitis, rhinorrhea \\
Plague & Buboes (huge lymphadenopathy), pneumonia \\
Cholera & Sudden-onset profuse watery diarrhea, early hypovolemic shock \\
Yellow fever & Jaundice \\
Influenza H1N1 & Flu-like illness*, severe disease and death in young adults \\
Influenza H3N2 & Flu-like illness* \\
Influenza H2N2 & Flu-like illness* \\
AIDS & Opportunistic infections, Kaposi's sarcoma of skin and viscera, profound emaciation \\
SARS & Severe pneumonia \\
Ebola & Bleeding from multiple sites \\
MERS & Severe pneumonia \\
COVID-19 & $\begin{array}{l}\text { Severe pneumonia, silent anoxia, anosmia, ageusia, toe lesions mimicking } \\
\text { chilblains, pediatric multisystem inflammatory syndrome }\end{array}$
\end{tabular}

* Fever, myalgia, respiratory symptoms, extreme weakness.

AIDS, acquired immune deficiency syndrome; COVID-19, coronavirus disease 2019; Flu, influenza; H1N1, hemagglutinin-1 neuraminidase-1; H2N2, hemagglutinin-2 neuraminidase-2; H3N2, hemagglutinin-3 neuraminidase-2; MERS, Middle East respiratory syndrome; SARS, severe acute respiratory syndrome.

of Health, was asked to develop a more detailed definition of pandemics. This gathering of infectious diseases specialists and epidemiologists proposed eight characteristics of pandemics (Table 3 ). ${ }^{2}$ Some of these characteristics relate to the microbe itself, while others are dependent on interaction between the microbe and the involved human population. A large number of books dealing with pandemics have

Table 3. Eight Characteristics of Pandemics.

The eight characteristics are related to the microbes themselves, or to the human-microbe interaction.*

\begin{tabular}{|c|c|}
\hline Feature & Comments \\
\hline Novelty & Mostly unknown to the medical profession \\
\hline Minimal population immunity & Frequent absence of specific IgG antibodies \\
\hline Explosiveness & $\begin{array}{l}\text { Determined mainly by size or density of population and factors } \\
\text { related to type of transmission, for example vector population }\end{array}$ \\
\hline Fast disease movement & Type and speed of human transmission \\
\hline Wide geographic extension & Social interaction of populations, widespread common source \\
\hline Infectiousness & Ability of microbes to produce disease (minimal infective dose) \\
\hline Contagiousness & $\begin{array}{l}\text { Proportion of completely asymptomatic cases, super-spreaders, } \\
\text { and evident and pathognomonic disease markers }\end{array}$ \\
\hline Severity & $\begin{array}{l}\text { Need for hospitalization, artificial ventilation, or intensive } \\
\text { rehydration; chronicity or death }\end{array}$ \\
\hline
\end{tabular}

* Examples of interacting human factors include background immunity, means of transmission, and healthcare system quality. 
been published, mainly during this last decade. ${ }^{2-38}$ Many web sites 39-44 and review articles have also reviewed the history of pandemics. Interestingly, there is a significant discordance in the inclusion or the exclusion of specific infectious diseases causing pandemics. Table 4 provides a chronological list of the major known pandemics reviewed in this article. $3^{2-44}$

\section{HISTORY OF PANDEMICS}

Obviously, written testimony on possible pandemics is lacking with regard to prehistoric times. However, it is important to recall that during the preagricultural era, the nomadic population of Homo sapiens on Earth was relatively small. Consequently, we can assume that pandemics were relatively rare

Table 4. Chronology of Known Pandemics.*

\begin{tabular}{|c|c|c|c|}
\hline Time & Name & Microbe & Death Toll \\
\hline $430 \mathrm{BC}$ & The plague of Athens & Rickettsia spp? Salmonella enterica spp? & $25 \%$ of population \\
\hline $165-180$ & Antonine plague & Smallpox? measles? & $5 M$ \\
\hline $541-542$ & Plague of Justinian & Yersinia pestis (Gram-negative bacteria) & $30-50 M$ \\
\hline $735-737$ & $\begin{array}{l}\text { Japanese smallpox } \\
\text { epidemic }\end{array}$ & Smallpox (DNA virus) & $1 \mathrm{M}$ \\
\hline $1347-1351$ & Black death & Yersinia pestis & $200 M$ \\
\hline 1520-onward & New world smallpox & Variola (smallpox) & $56 \mathrm{M}$ \\
\hline $1629-1631$ & Italian plague & Yersinia pestis & $1 \mathrm{M}$ \\
\hline $1665-1666$ & Great plague of London & Yersinia pestis & $100 \mathrm{~K}$ \\
\hline $1800 s^{\dagger}$ & Yellow fever & Yellow fever (RNA virus) & $100-150 K$ \\
\hline $1817-1923$ & Cholera pandemics & Vibrio cholera (Gram-negative bacteria) & $>1 \mathrm{M}$ \\
\hline 1885 & Third plague & Yersinia pestis & $12 M$ \\
\hline $1889-1890$ & Russian flu & Influenza H2N2? (RNA virus) & $1 \mathrm{M}$ \\
\hline $1918-1919$ & Spanish flu & Influenza H1N1 & $40-50 M$ \\
\hline $1957-1958$ & Asian flu & Influenza H2N2 & $1.1 \mathrm{M}$ \\
\hline $1968-1970$ & Hong Kong flu & Influenza H3N2 & $1 M$ \\
\hline 1981-present & AIDS & HIV (RNA virus) & $25-35 M$ \\
\hline $2002-2003$ & SARS & SARS-CoV-1 (RNA virus) & $0.8 \mathrm{~K}$ \\
\hline $2009-2010$ & Swine flu & Influenza H1N1 & $200 K$ \\
\hline $2014-2016$ & Ebola & Ebola virus (RNA virus) & $11 \mathrm{~K}$ \\
\hline 2015-present & MERS & MERS-CoV (RNA virus) & $0.8 \mathrm{~K}$ \\
\hline 2019-present & COVID-19 & SARS-CoV-2 (RNA virus) & $>0.5 \mathrm{M}$ \\
\hline
\end{tabular}

* Due to the lack of clear-cut definition of a pandemic, this table was compiled based on commonalities in multiple references. ${ }^{32-44}$

†There were more than 20 waves of Yellow fever in the 1800s; hence, a precise end-date cannot be given. AIDS, acquired immune deficiency syndrome; BC, before Christ; COVID-19, coronavirus disease 2019; DNA, deoxyribonucleic acid; flu, influenza; H1N1, hemagglutinin-1 neuraminidase-1; H2N2, hemagglutinin-2 neuraminidase-2; $\mathrm{H} 3 \mathrm{~N} 2$, hemagglutinin-3 neuraminidase-2; HIV, human immune deficiency virus; $K$, thousands; M, millions; MERS, Middle East respiratory syndrome; MERS-CoV, Middle East respiratory syndrome coronavirus; RNA, ribonucleic acid; SARS, severe acute respiratory syndrome; SARS CoV-1, severe acute respiratory syndrome coronavirus-1; SARS CoV-2, severe acute respiratory syndrome coronavirus-2. 
at that time. The known history of pandemics is based on the discoveries of documentation by ancient historians and other sources. Table 4 provides an overview of the known pandemics throughout history. ${ }^{32-38}$ Due to the lack of consensus on the definition of a pandemic, there are some cases in which there is a discrepancy regarding the categorization of an epidemic as a pandemic. For example, the SARS epidemic in 2002-2003 had all the characteristics of a potential dire pandemic, but fortunately its spread was interrupted by yet unexplained mechanisms. Some pandemics such as AIDS have been widespread both in time and in vast geographic distribution. 45 Current knowledge marks the 1930 s as the beginning of the human immune deficiency virus (HIV) epidemic, when zoonoses from Pan troglodytes troglodytes to humans occurred in Africa.46,47 Similarly, the cholera and plague pandemics had a zoonotic origin. 48,49
Figure 2 provides some illustrative examples of the human (panel A) and zoonotic (panels B and C) factors contributing to the spread of pandemics, and devices developed to help avoid their spread (panels $\mathrm{D}, \mathrm{E}$, and F).

Intriguingly, and according to databases managed by both Johns Hopkins University7 and the European Centre for Disease Prevention and Control, 8 plots of the daily global numbers of COVID-19infected persons during the second trimester of 2020 reveal an undulating and ascending pattern that is difficult to explain. However, they also show a progressive and steady decrease in mortality for that same period. 7 This last observation merits a logical explanation, but there has not been enough research to date to provide one. The cumulative number and type of mutations detected during the first 6 months
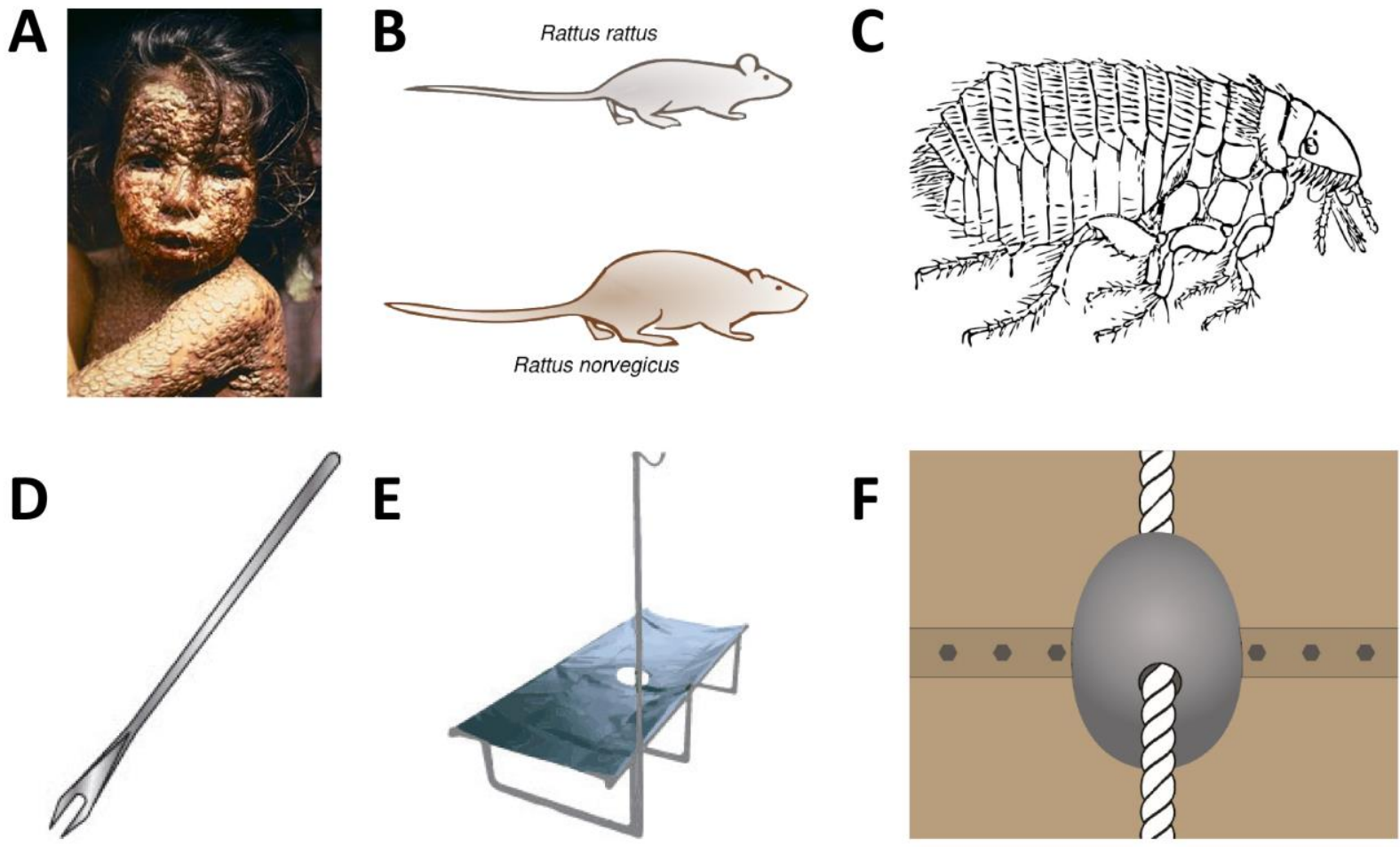

Figure 2. Illustrative Examples of Factors Affecting Spread (Top Row) or Control (Bottom Row) of Pandemics. A: Typical smallpox rash with extremely contagious pustular lesions. B: The two most common species of rats (reservoirs of Yersinia pestis). C: Xenopsylla cheopis (the rat flea), one of the vectors of Yersinia pestis, which transmits the infecting bacteria from rats to human beings. D: Bifurcated needle used for smallpox vaccination during the last decades of smallpox eradication. E: Cholera bed used to rehydrate patients with severe diarrhea; the drain in the middle is used to facilitate drainage of the copious diarrheal fluid. F: Cone barrier used to prevent rats from invading or leaving ships through the mooring ropes of the ship.

Panel A from Wikipedia.com, Public Domain by CDC/James Hicks; Panel B modified from Wikipedia.com (CC BY-SA 3.0); Panel C from Pixabay.com. 
of 2020 do not explain the reduced severity of SARS-CoV-2.50 Table 4 also demonstrates the predominance of RNA viruses as the cause of most pandemics, with the only exception being the variola virus, which is composed of DNA. Relatively few pandemics were caused by Gram-negative bacteria.

\section{Pandemics Originating Mainly in Tropical Areas}

Yellow fever epidemics occur mainly in Africa and South America. The disease is transmitted by several species of mosquitoes, mainly by Aedes aegypti. The disease life cycle has two possible scenarios: (1) the sylvatic cycle, where the hosts are various types of animals, primarily monkeys; and (2) the urban cycle, where the reservoir is human beings. Outbreaks occur mainly during the rainy season. Water accumulation, on land or in various objects, facilitates development of vector mosquitos. Other viruses transmitted by Aedes aegypti include dengue virus, Zika virus, and chikungunya virus. 34

For close to half a century, several Ebola virus outbreaks have occurred in Western and Central Africa. The long-term reservoir of this virus is a species of bats. Due to massive deforestation, there have been episodes of viral spillover to humans and animals, including gorillas and chimpanzees. Subsequently, human-to-human transmission occurred as the result of close contact with patients or bodies at burial ceremonies, and some convalescing patients continued to transmit the virus for some time after recovery. Due to the high contagiousness of Ebola, many health care workers were also infected. Currently, there is an effective vaccine to prevent Ebola (Table 5) as well as a drug composed of three types of antibodies (Table 6)..$^{1}$

Table 5. Vaccines for Pandemic Diseases.*

\begin{tabular}{l|c|cc}
\hline Disease & $R_{0}$ & Vaccine(s) & Current Number of Cases/Year \\
\hline Smallpox & $3.5-6$ & Yes $^{\dagger}$ & None \\
Measles & $12-18$ & Yes $^{\dagger}$ & $5 \mathrm{M}$ \\
Plague & $\ddagger$ & Yes $^{\dagger}$ & $0.5 \mathrm{~K}$ \\
Cholera & $\ddagger$ & Yes $^{\dagger}$ & $1.4-4 \mathrm{M}$ \\
Yellow fever & $\ddagger$ & Yes $^{5}$ & $200 \mathrm{~K}$ \\
Influenza H1N1 & $1.4-2.8$ & Yes $^{\dagger}$ & $>5 \mathrm{M}$; various types of influenza \\
Influenza H3N2 & 1.5 & Yes $^{\dagger}$ & $>5 \mathrm{M}$; various types of influenza \\
Influenza H2N2 & 1.5 & Yes $^{\dagger}$ & $>5 \mathrm{M}$; various types of influenza \\
AIDS & $\ddagger$ & None $^{\dagger}$ & $1.7 \mathrm{M}$ \\
SARS & $0.19-1.08$ & None $^{\dagger}$ & None \\
Ebola & $1.5-1.9$ & Yes $^{\dagger}$ & 0 -several thousands \\
MERS & $0.3-0.8$ & None & $0-0.3 \mathrm{~K}$ \\
COVID-19 & 2.5 & None & $>10 M^{* *}$ \\
\hline
\end{tabular}

* Only approved vaccines are included.

+ Various types available.

$\ddagger$ Difficult to assess.

${ }^{\S}$ Live attenuated vaccine, single shot gives life-time immunity.

** During a 6-month period.

AIDS, acquired immune deficiency syndrome; COVID-19, coronavirus disease 2019; H1N1, hemagglutinin-1 neuraminidase-1; H2N2, hemagglutinin-2 neuraminidase-2; H3N2, hemagglutinin- 3 neuraminidase-2; K, thousands; M, millions; MERS, Middle East respiratory syndrome; $R_{0}$, basic reproduction number; SARS, severe acute respiratory syndrome. 
Table 6. Treatment Used for Pandemic Diseases.*

\begin{tabular}{|c|c|}
\hline Disease & Treatment \\
\hline Smallpox & Tecovirimat $^{\dagger}$ \\
\hline Measles & Vitamin A \\
\hline Plague & Doxycycline $^{\ddagger}$ \\
\hline Cholera & $\begin{array}{l}\text { Massive rehydration; doxycycline (in adults) }{ }^{\ddagger} \text {; } \\
\text { azithromycin (in children) })^{\ddagger}\end{array}$ \\
\hline Yellow fever & None \\
\hline Influenza H1N1 & Oseltamivir ${ }^{\S}$ \\
\hline Influenza H3N2 & Oseltamivir ${ }^{\S}$ \\
\hline Influenza H2N2 & Oseltamivir $\S$ \\
\hline AIDS & $\begin{array}{l}>20 \text { antiviral drugs grouped in } 8 \text { classes and }>40 \\
\text { combinations of two or more drugs }\end{array}$ \\
\hline SARS & None \\
\hline Ebola & REGN-EB3** \\
\hline MERS & None \\
\hline COVID-19 & Remdesivir ${ }^{\dagger \dagger}$ \\
\hline
\end{tabular}

* Only approved drugs are included.

† Never used in humans. Two million doses stockpiled in the US, in case of bioterror attack.

$\ddagger$ Other effective antibiotics available.

$\S$ Other effective antivirals available.

** Includes three types of antibodies.

t† Several other antivirals under investigation.

AIDS, acquired immune deficiency syndrome; COVID-19, coronavirus disease 2019; H1N1, hemagglutinin-1 neuraminidase-1; H2N2, hemagglutinin2 neuraminidase-2; H3N2, hemagglutinin-3 neuraminidase-2; MERS, Middle East respiratory syndrome; SARS, severe acute respiratory syndrome.

\section{Influenza Pandemics}

During the twentieth century, there were four major pandemics: H1N1 caused the 1918 influenza pandemic; the pandemics of 1957,1958 , and 2009 were all descendants of the 1918 virus. The last of these pandemic influenza viruses incorporated genes by reassortment.

In general, annual seasonal influenza in postpandemic years is caused by variants of the corresponding virus from the prior pandemics. Influenza viruses involved in seasonal flu accumulate antigenic changes in a progressive fashion resulting in annual seasonal epidemics. An accepted parameter for the impact of annual influenza activity is the excess number of deaths. ${ }^{22,53}$ Interestingly, in 1977, a reemergence of human $\mathrm{H} 1 \mathrm{~N} 1$ viruses identical to those circulating before 1957 was attributed to an accidental "escape" of an old frozen laboratory specimen.

\section{THE IMPACT OF PANDEMICS ON HUMAN HISTORY}

Epidemics and pandemics have had a very strong impact on human history. Diseases like smallpox, measles, and plague decimated entire populations in several regions of Europe, the Middle East, and Asia. At the end of the fifteenth century, the European conquistadores of the Americas brought diseases with them that were unknown to the native population. Due to the local lack of immunity to these newly imported viruses, smallpox and measles spread rapidly, causing fear and frustration among the natives due to the lack of natural resistance and 
a very high mortality rate; local communities were decimated and sometimes entire settlements were wiped out. This tragedy facilitated the conquest of the land and the massive conversion of Indian tribes to Christianity across the Americas. 34

Beginning in the last decade of the twentieth century, the AIDS pandemic intensified its spread on all continents, inflicting the greatest damage in Africa at the social, economic, and political levels. Some of the manifestations of this megacatastrophe were the significant shortening of life expectancy, massive destruction of family units, and orphanhood. In addition, the profound immune suppression caused by HIV led to a rampant increase in the incidence and prevalence of tuberculosis and other infectious diseases. Combined, these factors had a disastrous effect on the political structure of most African countries. 34,35

Across history, pandemics have differentially infiltrated battling armies and in this way tipped the outcome of battles and war. 34

\section{PALEOMICROBIOLOGY}

During the last decades and as a valuable complement to the written documentation on ancient bacterial pandemics, paleomicrobiological studies relating primarily to the plague (Yersinia pestis) have contributed greatly to the reshaping of our understanding of its epidemiology. There was much confusion and controversy regarding the epidemiology of plague in the multiple pandemics that occurred several centuries ago, until the studies of French investigators, Drancourt and Raoult and colleagues, which revolutionized several contentious concepts established by other investigators. 54 Their work centered on the skeletal remains of common graves from various epochs. ${ }^{54-57}$ By examining the bacterial DNA in the pulp of relatively preserved teeth, they found genomic evidence for not only Yersinia pestis but also for Bartonella quintana, a bacterium transmitted by lice. 54,57 Since Yersinia pestis is also found in body lice, the investigators developed a laboratory rabbit model and exposed the animals to human lice infected with specific bacteria. Additional epidemics investigated by the same scientists were found to be caused by Bartonella quintana alone or combined with Rickettsia prowazekii.54 These and other studies supported the theory that infected lice were key spreaders of Yersinia pestis, sometimes found in polymicrobial infections.
With regard to smallpox, several well preserved mummies have been found in Egypt and other countries. Some mummies, such as that of the Egyptian pharaoh, Ramses V, provided dermal evidence that they had terminally suffered from smallpox. However, genomic evidence for the actual virus has been found only rarely in mummies. This can be explained by the poor long-term preservation of viruses. Other diseases documented by paleomicrobiological methodologies include tuberculosis, leprosy, and multiple parasitic infections. 54

\section{TRACING THE ORIGIN OF MICROBES AND THEIR ROUTE OF TRANSMISSION}

The past 30 years have seen rapid development of genetic sequencing technologies for RNA and DNA. $5^{8}$ From the beginning, RNA/DNA research has been characterized by both exaggerated promises and inflated expectations regarding the importance of human genetic traits that predispose for both infectious and non-infectious diseases. 59 Unfortunately, to date, no human genetic markers predisposing to SARS-CoV-2 infection, nor the severity of COVID19 , have been found-although recent isolated exceptions to this statement can be found. For example, there may be a predisposition to COVID-19 among humans with blood group A as opposed to other blood groups. ${ }^{60}$ In sharp contrast to human genomics, mapping viral RNA mutations of SARSCoV-2 has enabled a fairly accurate reconstruction of its transmission (Figure $3 \mathrm{~B}$ ) and helped to determine its phylogenetic origins (Figure 1 and Figure 3A).1,61 Viral sequencing of samples obtained from COVID-19 patients, and being able to mark its different mutations, has provided a much clearer and more accurate picture of viral transmission as opposed to results obtained by contact tracing. For example, a study of disease importation to continents, countries, or regions has surprisingly uncovered several shuffled patterns in the genomic data. When considering importation of the first COVID-19 cases to the Western United States, the initial investigation based on contact tracing indicated that those cases were epidemiologically unrelated. However, after sequencing multiple virus isolates, the researchers concluded that they were not only closely related, but probably also began with one patient of origin. ${ }^{62}$

A series of questions must be answered when attempting to determine the primary source of a 
A

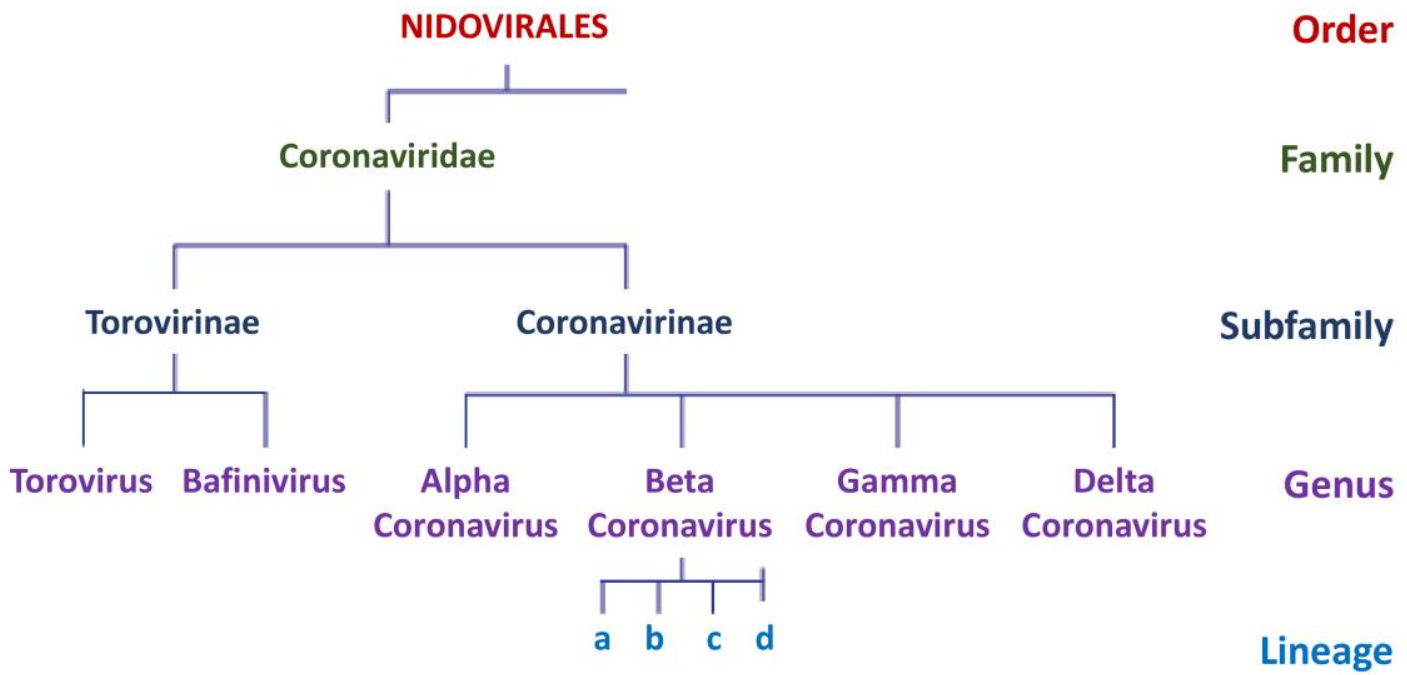

Species

B

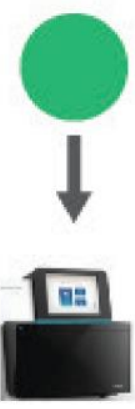

AUUU

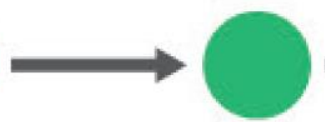

AUCU

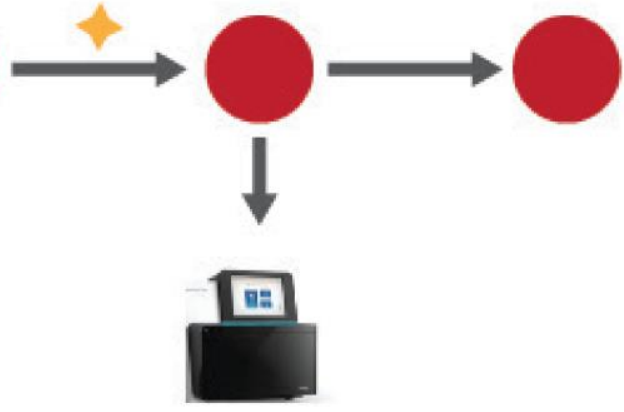

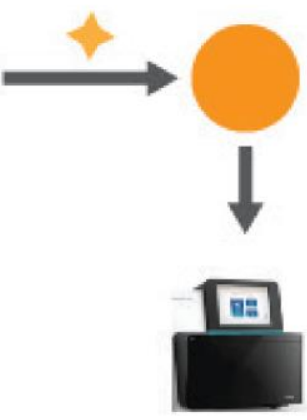

GUCU

\section{Mutation}

Figure 3. Genomics as a Useful Tool in Pandemics.

A: Sequencing of representative isolates to create a phylogenetic tree of a coronavirus. B: Tracing a pandemic pathway. Specific viral isolates are sequenced to detect mutation and thereby reconstruct the chain of transmission.

In panel B, each circle represents a coronavirus isolated from a patient. Different colors indicate a virus mutation. A genome sequencer device (machines in the figure) is used to determine the location and type of mutation: AUUU, a segment of the viral genome Adenine Uracil Uracil Uracil; AUCU, same segment of the genome after mutation Cytosine replacing middle Uracil; or GUCU, same segment of the genome following another mutation: Guanine replaced Adenine.

pandemic virus like SARS-CoV-2. As it is a coronavirus, the most probable source is a virus that originated in bats. ${ }^{6} 3$ To confirm this theory, genomic profiles of coronaviruses previously isolated from bats must be compared with coronavirus profiles isolated from patients. If these sequences are identical, then it can be assumed that the primary source is a bat. ${ }^{64}$ However, if the virus has been preserved 
in the refrigerators of a virology laboratory, there exists a very real possibility of viral "escape" from the laboratory to the community. In this scenario, especially if the laboratory is located in the proximity of the epidemic epicenter, a laboratory origin of the pandemic virus would be a strong alternative. Additional tests such as antibody testing of the personnel working in the suspected laboratory should provide further assistance in elucidating the true origin and pathway of the virus.

Other possible trajectories should also be investigated. For example, if early infections occurred in persons who had close contact to bats or other animals, such as animals raised on farms or held and sacrificed at wet markets, this would clearly point to a specific zoonotic link. Another possibility is that the new virus was engineered for investigational purposes or with malicious criminal intentions. By looking at the structural details of the virus, molecular biologists have ruled out and published the arguments against this last-mentioned possibility. 65

\section{MEASURING PANDEMICS}

The COVID-19 pandemic exemplifies the difficulties encountered when attempting to quantify the important numerical parameters of the disease. First of all, when trying to count the number of infected cases, this parameter is significantly underestimated, primarily because the proportion of people who are asymptomatic or suffering from mild disease are not yet known. ${ }^{66}$ Secondly, the initial shortage of laboratory kits has limited the number of people who can be ideally tested. ${ }^{67}$ The same problem arises when attempting to calculate the basic reproduction number, i.e. the number of persons who were infected by a certain patient. In this case, it is not easy to draw a line to those who should be considered a contact. ${ }^{68} \mathrm{~A}$ similar bias can interfere with calculation of the case fatality ratio, i.e. the proportion of infected persons who have died of COVID-19. In addition to underdetection of mainly asymptomatic patients, some deaths due to COVID-19 complications passed under the radar since the patients had not been tested for the virus. Last but not least, the sensitivity and specificity of viral tests are not $100 \%$, resulting in occasional false negative or false positive results. ${ }^{69} \mathrm{~A}$ complementary method to assess pandemic-related mortality is to measure excess deaths compared to previous years during the same season..$^{70}$ In order to retrospectively estimate the number of infected persons, serologic tests are performed that measure the presence of specific IgM and IgG antibodies to SARS-
CoV-2. Currently, there are many ongoing seroprevalence studies of anti-SARS-CoV-2 antibodies; however, the picture remains incomplete regarding the significance of these findings as markers of previous infections. ${ }^{71}$

\section{CONTAINMENT OF EPIDEMICS AND PANDEMICS}

In 1854 , a cholera outbreak erupted in the densely populated neighborhood of Soho, London. John Snow, a physician who lived in the vicinity, mapped the houses of the many affected persons with cholera. He discovered a water pump in the center of the mapped area that had been used by all infected persons for obtaining drinking water. On his advice, municipal authorities removed the pump handle, resulting in an immediate end to the epidemic, with no further cases. It was subsequently learned that human excrement pits had drained into and contaminated the water supply. ${ }^{72}$ This brilliant epidemiological investigation led to John Snow being considered the "Father of epidemiology." 73

In the 1990s a major epidemic of cholera occurred in Peru. Vibrio cholera contaminated the ballast water in ships that had arrived from India. Massive contamination of large quantities of live fish occurred when the ballast water was discharged into the sea near the shore. Fish were subsequently caught from this area, and thousands of Peruvians developed cholera after consuming raw fish (ceviche), a popular traditional food. The epidemic was terminated abruptly when the health authorities recommended to discard the head and branchia (gills) when preparing the fish for consumption. 74

Following the spread of the COVID-19 pandemic, the health authorities of most countries imposed a lockdown with various intervals of delay from the first detected case(s) so as to contain the local spread of the virus. Subsequently, they also imposed the use of respiratory masks to reduce airborne transmission by infected persons and to prevent contagion among the uninfected population. Data from several countries have shown that the earlier and more stringent the lockdown was applied, the better the efforts in containing the pandemic. 75

\section{Vaccines for Prevention of Pandemic Diseases}

Vaccines are human-made molecular tricks aimed at cheating the immune system of the host, to make it "believe" that it has encountered a microorganism- 
causing disease (Professor Myron Levine, personal communication). Table 5 lists the current availability of approved vaccines for pandemic diseases. Paradoxically, some of the newer diseases such as AIDS and those caused by coronaviruses still lack an approved effective vaccine. On the other hand, smallpox, a very old but already eradicated disease, was (to the best of our knowledge) the first disease for which several types of "natural" empiric vaccines were used, initially by the Chinese in ancient times, 76 and subsequently by Edward Jenner in England in the eighteenth century.76,77 Interestingly, vaccination with smallpox vaccines was implemented several centuries before the discovery of viruses in general, and variola and vaccinia viruses in particular.

As recently summarized by the WHO, 78 there are currently at least 125 different COVID-19 vaccination research projects underway in the quest to prevent COVID-19. Essentially, six groups of vaccines are being explored, three of which first require the isolation of viral particles. These virions are either: (1) weakened (attenuated); (2) killed by hot or chemical substances (inactivated); or (3) fragmented viruses followed by isolation of small pieces of the virus (subunits). A second class of vaccine starts with genetically engineered pieces of either RNA or DNA, which subsequently are embedded in either: (4) plasmids (DNA); (5) lipids (RNA); or (6) an adenovirus vector.79 In all cases, particles are diluted in a solution for initial animal testing (preclinical trials) and subsequent testing in humans (clinical trials).

Clinical trials are performed in three phases, each one having an increasing number of volunteers. Phase I (10-100 volunteers) examines safety and immunogenicity. Phase II (>100 volunteers) examines safety, immunogenicity, and dose adjustments. Phase III (more than 10,000 volunteers) primarily examines infection prevention following exposure. If all three phases are successful, then the vaccine undergoes regulatory approval and subsequent mass production under strict quality control.

The main problem with the need to develop a vaccine against a new pandemic microbe is that the process is lengthy and mined with multiple obstacles. ${ }^{80,81}$ In the past, the elapsed time from vaccine development to approval and production could take up to 10 years. However, in order to efficiently and rapidly cope with an emerging pandemic, ideally, the scientific world must be prepared with predefined "templates" to facilitate accelerated vaccine development. If a proposed vaccine causes serious side effects or alternatively is not sufficiently immunogenic, the development process should be restarted from the beginning. In some cases, when a clinical evaluation of a vaccine reaches Phase III, the number of newly infected cases drops rapidly, making it difficult to test the actual efficacy of the vaccine in preventing infection. In the quest for a COVID-19 vaccine, there have been a few initiatives to recruit volunteers who would be challenged with the virus after being immunized. However, for this scheme to work, it is essential to have a very efficacious drug available for treating the infection, should the vaccine fail.

\section{Drugs to Treat Pandemic Diseases}

In general, with regard to the efficacy of antiviral treatments, viral infections can be divided into three groups: (1) infections lacking an effective antiviral therapy (e.g. SARS, yellow fever, measles); (2) infections in which antivirals do not cure the infection, but which do produce varying degrees of clinical improvement (e.g. influenza, AIDS, COVID-19); and (3) infections that can be cured by antiviral therapy (e.g. Ebola, hepatitis C). Table 6 provides an overview of the treatments used for different pandemic diseases.

Despite an increase in antibiotic resistance, there remain multiple choices for treatment of bacterial pandemics. For example, the main pillar of medical treatment for cholera is the emergency replacement of large amounts of fluid lost as a result of diarrhea and vomiting, with antibiotics playing a secondary role in its treatment. The fatality ratio of untreated cholera is around 50\%. However, prompt administration of appropriate amounts of fluids either orally or intravenously decreases the case fatality ratio to $1 \% .48$

The overwhelming death toll from COVID-19 has sparked a myriad of projects to identify drugs that can be repurposed on a fast track to for special treatment of patients with severe disease. ${ }^{6}$ In the meantime, the only drug that has shown some beneficial results in a double-blind randomized clinical trial compared to placebo is the antiviral remdesivir, which has been approved by the US Food and Drug Administration and other regulatory institutions. ${ }^{82}$

The administration of convalescent plasma from recovering patients with COVID-19 is now being examined at different sites, including new clinical trials, but conclusions regarding this therapy are still pending. ${ }^{83}$ 


\section{ECONOMIC IMPACT OF COVID-19}

The economic impact of past pandemics is hard to examine due to the lack of robust data. ${ }^{84}$ However, a retrospective look at the first 6 months of the COVID-19 epidemic reveals a catastrophic impact on the economies of most countries having to cope with significant numbers of cases. The harshest economic impact generally occurred in varying degrees in wealthier countries. One of the most important parameters for quantifying economic damage is the gross domestic product forecast, although different countries use other economic metrics. According to the majority of prognoses, the damage was expected to be greatest during the second quarter of 2020 . The primary reason for the severe economic impact of COVID-19 has been the leading and widely justified slogan, "health before wealth." Another parameter that has significantly contributed to the economic crisis worldwide is the swift increase in job losses. Quantification of financial activities in selected populations may add important data to more accurate evaluation of the world economy as a result of the COVID-19 pandemic. For example, listing the purpose of out-of-home visits (residential, parks, workplace, grocery stores, pharmacy) may contribute to a composite financial evaluation of representative family units. ${ }^{84,85}$

\section{CONCLUSION}

Despite the rapid and advanced progress in many medical disciplines since the end of the nineteenth century, the COVID-19 pandemic has sadly demonstrated vast limitations worldwide in successfully coping with it. There is no doubt that the unexpected and yet fully unknown behavior of SARS-CoV-2 has strongly contributed to its pandemic status. For example, the high proportion of infected but totally asymptomatic persons has made containment challenging, to say the least. In some cases, the proportion of infected persons feeling absolutely well can approach almost 90\%. ${ }^{86}$ For example, a COVID-19 outbreak occurred on a cruise ship departing Ushuaia in the province of Tierra del Fuego, Argentina, and navigating to the Antarctic peninsula. Sampling the entire population on board revealed that a vast majority had contracted the infection, but $80 \%$ of them were asymptomatic patients. ${ }^{86}$ Another tricky characteristic of the virus is that infected patients expelled virus particles through their respiratory tract, primarily during the early phases of the incubation period before they became symptomatic.
Selected examples from prior pandemics should illuminate our vision for the future. Smallpox went from being a totally empiric vaccine to global eradication of the disease. However, AIDS, which is caused by a zoonotic retrovirus that translates its RNA to DNA and enters the human genome, presents an almost impossible challenge in approaching a total cure for the disease, although combinations of antivirals are able to halt or reverse the progression of the disease.

This retrospective analysis and comparison of COVID-19 with prior pandemic diseases can contribute to the improvement of a rationale and scientific approach to future epidemics or pandemics. The most important take-away point should be an understanding of the high degree of preparedness that is needed, including various protocols for social distancing that are adapted to the different transmission modalities of the involved microbes. In addition, multiple innovative protocols aimed at a robust accelerated vaccine development process are needed. Disease-causing viruses, or colonizing species in the animal kingdom, should be evaluated for potential spillage to human beings. For those specific viruses, it is imperative to delineate seminal protocols that can be launched in emergency situations.

Recently, the New York times launched two very recent dynamic applications that allow tracking the daily status of 20 therapies and 155 vaccines for COVID-19. 87,88 Readers can visit these sites to access updates regarding ongoing developments related to COVID-19 vaccines and treatments.

Finally, the conclusion of this paper, at this point in time, is to stress the importance of ongoing refinement of interactions between government leaders, scientists, and economists, at both the national and international levels, so as to better grapple with the current (and any future) pandemic, as it unfolds.

\section{REFERENCES}

1. Genomic epidemiology of novel coronavirus - Global subsampling. Updated June 2020. Available at: https://nextstrain.org/ncov/global (accessed July 2, 2020).

2. Guan WJ, Ni ZY, Hu Y, et al. Clinical characteristics of coronavirus disease 2019 China. N Engl J Med 2020;382:1708-20. $\underline{\text { CrossRef }}$

3. Tay MZ, Poh CM, Rénia L, MacAry PA, Ng LFP. The trinity of COVID-19: immunity, inflammation and 
intervention. Nat Rev Immunol 2020;20:363-74. CrossRef

4. Moderna website. Moderna's Work on a COVID-19 Vaccine Candidate. 2020, Moderna, Inc. Available at: https://www.modernatx.com/modernas-workpotential-vaccine-against-covid-19 (accessed July 2, 2020).

5. Inovio Urgently Focused On Developing Covid-19 Vaccine: Because the World Can't Wait. Inovio Website. 2020, Inovio Pharmaceuticals. Available at: https://www.inovio.com/our-focus-servingpatients/covid-19/ (accessed July 2, 2020).

6. Gordon DE, Jang JM, Bouhaddou M, et al. A SARSCoV-2 protein interaction map reveals targets for drug repurposing. Nature 2020; April 30. Online ahead of print. $\underline{\text { CrossRef }}$

7. Johns Hopkins University \& Medicine website. Coronavirus Resource Center. Available at: https:// coronavirus.jhu.edu/ (accessed July 2, 2020).

8. European Centre for Disease Prevention and Control. COVID-19 pandemic. Available at: https://www.ecdc. europa.eu/en/covid-19-pandemic (accessed July 2, 2020).

9. Kim D, Lee JY, Yang JS, Kim JW, Kim VN, Chang H. The architecture of SARS-CoV-2 transcriptome. Cell 2020;181:914-21. CrossRef

10. Sternberg A, McKee DL, Naujokat C. Novel drugs targeting the SARS-CoV-2/COVID 19 machinery. Curr Top Med Chem 2020;20:1423-33.

11. Shereen MA, Kahn S, Kazmi A, Bashir N, Siddique R. COVID-19 infection: origin, transmission, and characteristics of human coronaviruses. J Adv Res 2020; 24:91-8. CrossRef

12. Hussain M, Jabeen N, Raza F, et al. Structural variations in human ACE 2 may influence its binding with SARS-CoV-2 spike protein. J Med Virol 2020; April 6. Online ahead of print. CrossRef

13. Tai W, He L, Zhang X, et al. Characterization of the receptor binding domain (RBD) of 2019 novel coronavirus: implications for development of RBD protein as a viral attachment inhibitor and vaccine. Cell Mol Immunol 2020;17:613-20. CrossRef

14. Li Y, Zhov W, Yang L, You R. Physiological and pathological regulation of ACE2, the SARS-CoV-2 receptor. Pharmacol Res 2020;157:104833. CrossRef

15. Zhou Y, Hou Y, Shen J, Huang Y, Martin W, Cheng F. Network-based drug repurposing for novel coronavirus 2019 -nCoV/SARS-CoV-2. Cell Discov 2020;6: 14. $\underline{\text { CrossRef }}$

16. Combs S. She discovered coronaviruses decades agobut got little recognition. National Geographic 2020; April 17. Available at: https://www.national- geographic.com/history/2020/04/june-almeidadiscovered-coronaviruses-decades-ago-littlerecognition/ (accessed July 8, 2020).

17. Bingham RW, Almeida JD. Studies on the structure of a coronavirus-avian infectious bronchitis virus. $\mathrm{J}$ Gen Virol 1977;36:495-502. CrossRef

18. Banerjee A, Kulcsar K, Misra V, Frieman M, Mossman K. Bats and coronaviruses. Viruses 2019;11:1-15. CrossRef

19. Ye ZW, Yuan S, Yuen KS, Fung SY, Chan CP, Jin DY. Zoonotic origins of human coronaviruses. Int J Biol Sci 2020;16:1686-97. CrossRef

20. Ye Q, Wang B, Mao J, et al. Epidemiological analysis of COVID-19 and practical experience from China. $\mathrm{J}$ Med Virol 2020;92:755-69. CrossRef

21. Zhang T, Wu Q, Zhang Z. Probably pangolin origin of SARS-CoV-2 associated with the COVID-19 outbreak. Curr Biol 2020;30:1346-51.e2. CrossRef

22. Hirano T, Murakami M. COVID-19: a new virus, but a familiar receptor and cytokine release syndrome. Immunity 2020;52:731-3. CrossRef

23. Tobin MJ. Basing respiratory management of COVID-19 on physiological principles. Am J Respir Crit Care Med 2020;201:1319-20. CrossRef

24. Bansal M. Cardiovascular disease and COVID-19. Diabetes Metab Syndr 2020;14:247-50. $\underline{\text { CrossRef }}$

25. Sun J, Aghemo A, Forner A, Valenti L. COVID-19 and liver disease. Liver Int 2020;40:1278-81. CrossRef

26. El-Azhary R. Re: Chilblain-like lesions on feet and hands during COVID-19 epidemic. Inter J Dermatol 2020;59:748. $\underline{\text { CrossRef }}$

27. Connors JM, Levy JH. COVID-19 and its implications for thrombosis and anticoagulation. Blood 2020;135: 2033-40. CrossRef

28. Ahmad I, Rathore FA. Neurological manifestations and complications of COVID-19: a literature review. J Clin Neurosci 2020;77:8-12. CrossRef

29. Cheng Y, Luo R, Wang $\mathrm{K}$, et al. Kidney disease is associated with in-hospital death of patients with COVID-19. Kidney Int 2020;97:829-38. CrossRef

30. Viner RM, Whittaker E. Kawasaki-like disease: emerging complication during the COVID-19 pandemic. Lancet 2020;395:1741-3.

31. World Health Organization (WHO). What is a Pandemic? 2010; February 24. Available at: https:// www.who.int/csr/disease/swineflu/frequently asked questions/pandemic/en/ (accessed July 2, 2020).

32. McMillen CW. Pandemics: A Very Short Introduction. Oxford, UK: Oxford University Press; 2016. ISBN-13: 978-0199340071. 
33. University Press. Pandemics: A Brief History. University Press; 2020. ISBN-13: 979-8635046531

34. Oldstone MBA. Viruses, Plagues \& History: Past, Present and Future. New York, NY; Oxford University Press; 2010. ISBN-13: 978-0195327311

35. Levine AJ. Viruses: A Scientific American Library Book. New York, NY; Scientific American Library; 1991. ISBN-13: 978-0716750314

36. Zimmer C. A Planet of Viruses. 2nd ed. Chicago, IL: The University of Chicago Press; 2015. ISBN-13: 9780226294209

37. Holmes EC. The Evolution and Emergence of RNA Viruses. Oxford Series in Ecology and Evolution. Oxford, UK: Oxford University Press; 2009. ISBN-13: 978-0199211135

38. Prestone T. Pandemic: A Brief History of Influenza, The Plague, Cholera, and Other Infectious Diseases That Have Changed the World; How They Started, How They Ended, and The Lessons Learned by Humanity. Prestone Theodore; 2020. ASIN: Bo87WH75BT

39. Jarus O. 20 of the worst epidemics and pandemics in history. Live Science website. Available at: https:// www.livescience.com/worst-epidemics-andpandemics-in-history.html (accessed July 2, 2020).

40. MPHonline. Outbreak: 10 of the worst pandemics in history. Available at: https://www.mphonline.org/ worst-pandemics-in-history/ (accessed July 2, 2020).

41. Roos D. How 5 of history's worst pandemics finally ended. History website. Available at: https://www. history.com/news/pandemics-end-plague-cholerablack-death-smallpox (accessed July 2, 2020).

42. LePan N. Visualizing the history of pandemics. Visual Capitalist website. March 14, 2020. Available at: https://www.visualcapitalist.com/history-ofpandemics-deadliest/ (accessed July 2, 2020).

43. Centers for Disease Control and Prevention. Influenza (flu): past pandemics. Available at: https://www. cdc.gov/flu/pandemic-resources/basics/pastpandemics.html (accessed July 2, 2020).

44. Robinson D, Battenfield A. The worst outbreaks in U.S. history. Healthline website. Available at: https:// www.healthline.com/health/worst-diseaseoutbreaks-history (accessed July 2, 2020).

45. Greene WC. A history of AIDS: looking back to see ahead. Eur J Immunol 2007;37(Suppl 1):S94-102. CrossRef

46. Huminer D, Rosenfeld JB, Pitlik SD. AIDS in the preAIDS era. Rev Infect Dis 1987;9:1102-8. CrossRef
47. Sharp PM, Hahn BH. The evolution of HIV-1 and the origin of AIDS. Philos Trans R Soc Lond B Biol Sci 2010;365:2487-94. CrossRef

48. Clemens JD, Nair JB, Ahmed T, Qadri F, Holmgren J. Cholera. Lancet 2017;390:1539-49. CrossRef

49. Raoult D, Mouffok N, Bitam I, Piarroux R, Drancourt M. Plague: history and contemporary analysis. J Infect 2013;66:18-26. CrossRef

50. Lau SY, Wang P, Mok BWY, et al. Attenuated SARS$\mathrm{CoV}-2$ variants with deletions at the $\mathrm{S} 1 / \mathrm{S} 2$ junction. Emerg Microbes Infect 2020;9:837-42. $\underline{\text { CrossRef }}$

51. Feldmann H, Sprecher A, Geisbert TW. Ebola. N Engl J Med 2020;382:1832-42. $\underline{\text { CrossRef }}$

52. Taubenberger JK, Kash JC, Morens DM. The 1918 influenza pandemic: 100 years of questions answered and unanswered. Sci Transl Med 2019;11:eaau5485. $\underline{\text { CrossRef }}$

53. Sarda C, Palma P, Rello J. Severe influenza: overview in critically ill patients. Curr Opin Crit Care 2019;25: 449-57. CrossRef

54. Drancourt M, Raoult D, eds. Paleomicrobiology of Humans. 1st ed. Washington DC: ASM Press; 2016. ISBN-13: 978-1555819163

55. Angelakis E, Bechah Y, Raoult D. The history of epidemic typhus. Microbiol Spectr 2016;4. CrossRef

56. Raoult D. A personal view of how paleomicrobiology aids our understanding of the role of lice in plague epidemics. Microbiol Spectr 2016;4. CrossRef

57. Drali R, Mumcuoglu K, Raoult D. Human lice in paleoentomology and paleomicrobiology. Microb Spectr 2016;4. CrossRef

58. Levy SE, Myers RM. Advancements in next-generation sequencing. Annu Rev Genomics Hum Genet 2016; 17:95-115. $\underline{\text { CrossRef }}$

59. Lek M, Karczewski KJ, Minikel EV, et al. Analysis of protein-coding genetic variation in 60, 706 humans. Nature 2016;536:285-91. CrossRef

60. Göker H, Krakulak EA, Demiroğlu HD, et al. The effects of blood group types on the risk of COVID-19 infection and its clinical outcome. Turk J Med Sci 2020; June 4. Online ahead of print. CrossRef

61. Rambaut A. Phylogenetic analysis of nCoV-2019 genomes. 2020; March 2. Virological website. Available at: https://virological.org/t/phylodynamic-analysis176-genomes-6-mar-2020/356 (accessed July 8, 2020).

62. Baker M, Fink S. COVID-19 arrived in Seattle. Where it went from there stunned the scientists. The New York Times 2020; April 22. Available at: https:// 
www.nytimes.com/2020/04/22/us/coronavirussequencing.html (accessed July 2, 2020).

63. Zhou P, Yang XL, Wang XG, et al. A pneumonia outbreak associated with a new coronavirus of probable bat origin. Nature 2020;579:270-3. CrossRef

64. Lu R, Zhao X, Li J, et al. Genomic characterization and epidemiology of 2019 novel coronavirus: implications for virus origins and receptor binding. Lancet 2020;395:565-74. CrossRef

65. Andersen KG, Rambaut A, Lipkin WI, Holmes EC, Garry RF. The proximal origin of SARS-CoV-2. Nat Med 2020;26:450-2. CrossRef

66. Gao Z, Xu Y, Sun C, et al. A systematic review of asymptomatic infections with COVID-19. J Microbiol Immunol Infect 2020; May 15. Online ahead of print. CrossRef

67. Yelin I, Aharoni N, Tamar ES, et al. Evaluation of COVID-19 RT-q PCR test in multi-sample pools. Clin Infect Dis 2020; May 2:ciaa531. Online ahead of print. CrossRef

68. Zhou T, Liu Q, Yang Z, et al. Preliminary prediction of the basic reproduction number of the Wuhan novel coronavirus 2019-nCoV. J Evid Based Med 2020; 13:3-7. CrossRef

69. Long C, Xu H, Shen Q, et al. Diagnosis of the coronavirus disease (COVID-19): rRT-PCR or CT? Eur J Radiol 2020;126:108961. CrossRef

70. Nogueira PJ, Nobre MA, Nicola PJ, Furtado C, Carneiro AV. Excess mortality estimation during the COVID-19 pandemic: preliminary data from Portugal. Acta Med Port 2020;33:376-83. CrossRef

71. Rashid ZZ, Othman SN, Samat MNA, Ali UK, Wong KK. Diagnostic performance of COVID-19 serology assays. Malays J Pathol 2020;42:13-21.

72. Snow J. Cholera and the water supply in the South districts of London. J Public Health Sanit Rev 1856; 2:239-57.

73. Vachon D. Part One: Doctor John Snow Blames Water Pollution for Cholera Epidemic. UCLA Department of Epidemiology, Fielding School of Public Health. 2005. Available at: https://www.ph.ucla.edu/ epi/snow/fatherofepidemiology.html (accessed July 2,2020 ).

74. Seas C, Miranda J, Gil AI, et al. New insights on the emergence of cholera in Latin America during 1991: the Peruvian experience. Am J Trop Med Hyg 2000;62:513-17. $\underline{\text { CrossRef }}$

75. Ghosal S, Bhattacharyya R, Majumder M. Impact of complete lockdown on total infection and death rates: a hierarchical cluster analysis. Diabetes Metab Syndr 2020;14:707-11. CrossRef

76. Morgan AJ, Poland GA. The Jenner Society and the Edward Jenner Museum: tributes to a physicianscientist. Vaccine 2011;29(Suppl 4):D152-4. CrossRef

77. Kennedy RB, Ovsyannikova I, Poland GA. Smallpox vaccines for biodefense. Vaccine 2009;27:D73-9. CrossRef

78. World Health Organization (WHO). Draft landscape of COVID-19 candidate vaccines. June 29, 2020. Available at: https://www.who.int/publications/ $\mathrm{m} /$ item/draft-landscape-of-covid-19-candidatevaccines (accessed July 2, 2020).

79. Callaway E. The race for coronavirus vaccines: a graphical guide. Nature 2020;580:576-7. CrossRef

80. Le TT, Andreadakis Z, Kumar A, et al. The COVID-19 vaccine development landscape. Nature Rev Drug Discov 2020;19:305-6. CrossRef

81. Chen WH, Strych U, Hotez PJ, Bottazzi ME. The SARS-CoV-2 vaccine pipeline: an overview. Current Trop Med Rep 2020;7:61-4. CrossRef

82. Beigel JH, Tomashek KM, Dodd LE, et al. Remdesivir for the treatment of COVID-19 - preliminary report. N Engl J Med 2020; May 22. Online ahead of print. CrossRef

83. Bloch EM, Shoham S, Casadevall A, et al. Deployment of convalescent plasma for the prevention and treatment of COVID-19. J Clin Invest 2020;130:2757-65. CrossRef

84. Gans J. Economics in the Age of COVID-19. Cambridge, MA; The MIT Press; 2020. ISBN: 978-0-26236279-5

85. Capital Economics. The economic impact of COVID19. July 2, 2020. Available at: https://www.capital economics.com/the-economic-effects-of-thecoronavirus/ (accessed July 2, 2020).

86. Ing AJ, Cocks C, Green JP. COVID-19: in the footsteps of Ernest Shackleton. Thorax 2020; May 27. Online ahead of print. $\underline{\text { CrossRef }}$

87. Corum J, Wu KJ, Zimmer C. Coronavirus drug and treatment tracker. The New York Times 2020; updated July 20. Available at: https://www.nytimes. com/interactive/2020/science/coronavirus-drugstreatments.html (accessed July 21, 2020).

88. Corum J, Grady D, Wee S-L, Zimmer C. Coronavirus vaccine tracker. The New York Times 2020; updated July 21. Available at: https://www.nytimes.com/ interactive/2020/science/coronavirus-vaccinetracker.html 